\title{
Innovativeness and Information Processes in the High-Tech Environment
}

\author{
Mieczysław Muraszkiewicz \\ Faculty of Economics and Informatics in Vilnius, Lithuania \\ Branch of the University of Bialystok
}

\begin{abstract}
Purpose/Thesis: The purpose of the study is to examine the relationship among modernization, innovativeness, and information processes in high-technology environments, and provide recommendations on boosting innovativeness, taking the informational dimension of innovation into account. Currently, knowledge and innovations have become the driving force of the world development. It is claimed that innovativeness, as opposed to inventiveness, can be subject to planning and management and as such is usually developed mostly in high-tech organizations and enterprises.

Approach/Methods: The method enabling high-tech organizations to create favorable conditions in order to boost innovativeness and develop innovations includes, inter alia: (i) encouraging such organizations and companies to build points of bifurcations within their own structures and business processes where free creative thoughts and experiments could happen; (ii) integrating main information systems that support innovativeness (e.g. systems dealing with company products and know-how, human resources, knowledge management, customer relationships management, and crowdsourcing). The corporate portal seems to be the most appropriate place for such integration, (iii) tapping into the model of open innovation and (iv) offering mobile access to corporate resources. Results and conclusions: The outcome of the research is the outline of a methodology for boosting innovativeness in high-tech environments that may help company managers and decision makers to organize innovation projects.

Originality/Value: The value of the research consists in the recognition of the fact that innovation within the high-tech environment needs to be organized, managed and provided with a reliable information support. The latter can be achieved with the integration of various information processes related to the implementation of innovation projects within a corporate portal.
\end{abstract}

Keywords

High-tech. ICT. Innovation. Knowledge society. Mobile technology. Modernization. Process integration.

Received: 10 December 2017. Reviewed: 19 December 2017. Accepted: 21 December 2017.

\section{About Modernisation and Innovativeness}

Given a large complexity and speed of the present high-tech world and business, a broader contextual outlook including social, political and even philosophical aspects is necessary while thinking of its evolution and prospects, especially when it comes to innovation that is one of the mainsprings of change.

Today, when vivid debates and hot discussions sometimes leading to serious political conflicts, on the choice whether we need more liberalism and free market or we should 
strengthen and advance the achievements of the welfare state take place in Europe, it seems that those protagonists are right who argue that this dilemma is misleading (Blair, 2005). The real game about the present and future patterns, people's betterment and social cohesion, the role and rules of business making, and about maintaining our cultural and political identity is played on a different ground. The point is not to confront liberalism with social solidarity and welfarism. This game is about something different; it is about modernisation. The subject of the game is to understand, accept and absorb the changes caused by faster and faster developments of technology, especially the information and communications technology, mobile technology, new management techniques, and new financial mechanisms, which transform economic and political spheres and change the very fabric of social architecture and social capital. It is also about setting up new schemes, patterns and procedures to replace the existing dysfunctional ones and to discontinue all the features that are obsolete and counterproductive. We claim that substantial part of social attention and energy should be drawn and channelled to boost modernisation, in particular its high technology facets and information processes of different kind, scope and coverage, rather than to be engaged in fruitless disputes on the advantages of liberalism over welfarism, or vice versa. Undoubtedly, should the modernisation endeavour be carried on, this dilemma will turn out irrelevant.

At the outset, let us elaborate a bit on the meaning of the term "modernisation". Is it a straight continuation of the Enlightenment project initiated by French and British thinkers, philosophers, scientists of the seventeenth and eighteenth centuries, which by means of the driving forces of capitalism has led the so-called Western countries to economic, military and political power? Or, perhaps, as Friedrich Nietzsche already argued, it is the reason of overwhelming nihilism, labour alienation, human's reification, and as his followers such as Theodor Adorno and Max Horkheimer of the Frankfurt School added, a reason of modern evil such as fascism, Bolshevik's tyranny and cruel wars of the twentieth century (Horkheimer \& Adorno, 2002). Undoubtedly, modernisation includes both threats, however, in different proportions over time. It is the force that has two faces, a sword of two edges. After the twentieth century lessons of sheer barbarism, after the ecological catastrophes caused by the abuse and immaturity of technology, for instance in the nuclear power plant of Chernobyl or Fukushima or chemical factory in Indian Bhopal, it seems today that by means of these experiences, political reason, and social awareness we are able to minimise negative consequences of modernisation, and to exploit and enjoy its indubitable potential to improve and enrich the quality of our life.

Here, we understand modernisation broadly, i.e. from simple technological improvements facilitating day-to-day life, to new technologies and their various applications systematically integrated with the social and economic fabric of the society, to new financial, organisational, educational, political and social models. Modernisation is thus not limited to the area of economics; it is a process of a much larger reach, encompassing practically all aspects of our life. The main mechanisms of modernisation are various policies, methodologies and tools that are used to devise, shape and organise social processes and economy based on knowledge and relaying on the achievements of science and technology. Such terms as "information society" or "knowledge society" used in the context of a modernisation discourse reflect a common conviction that information and knowledge are key factors of modernisation processes. 
It is now worthwhile to ask: What is the link that joins information and knowledge with the practice of production and organisational processes occurring in the knowledge society, or in other words, to ask about an operational factor of modernisation? We believe that one of such factors which is particularly important and directly influencing our present and future life is innovativeness. The innovations are this force that transforms discoveries, research and experiments outcomes in a variety of applications and new solutions, which have a direct impact on the form, appearance and structure of the world. If we assume that research and discoveries is the engine of modernisation processes, then we can legitimately consider innovations a fuel for this engine that affects its efficiency and effectiveness. This is not a new opinion and appreciation of the innovation's role. We can find a similar belief expressed in a slightly different manner in the classic book by the Austrian-American economist Joseph A. Schumpeter entitled The Theory of Economic Development already published in 1911 (Schumpeter, 1934), which almost a hundred years later provided an intellectual background for the promotion of innovativeness as an important building block and a mainspring of societal development strategies, lately so eagerly employed by the European Commission in its Lisbon Strategy (The Lisbon European Council, 2000).

Innovativeness has been subject to a great deal of papers, reports books, seminars, workshops, and conferences. It seems however that in this ocean of proposals, models, and methodologies still there is an epistemological gap. Namely, one has not managed to work out an approach to innovativeness in which social life or professional life is a starting point of innovation endeavour rather than business reasons such as profit or technological reason like the improvement or enhancement of device functionality. In this approach life should be considered as a multithread well-ordered and organised process including many actors, in which, however, suddenly come out particular points where as a result of original, fresh, non-routine thinking and acting new elements emerge. This is the moment of disruption when a new product or service disrupts an existing setting (e.g. a segment of a market) and value network. The phenomenon of "disruptive innovation", as well as this very term, was identified, analysed and introduced to the innovation discourse by the American scholar Clayton M. Christensen in the mid of the last decade of the previous century, and now is recognised as one of the most influential business idea of the early 21st century (Dyer et al., 2011).

We have already arrived at the point where an explanatory remark has to be made. One has to distinguish innovation from discovery, innovativeness from inventiveness. Innovativeness consists in a new use of the existing techniques, technologies and/or devices to set up new solutions, goods, services or processes. Innovativeness is a creative exploitation of the known things, yet, in a new way, in a new situation or for reaching a new objective. Inventiveness, however, is different for it is aimed at creating entirely new things that have not existed so far. When Sir Winston Churchill was the First Lord of Admiralty in 1911 he initiated a series of deep reforms. Perhaps the most important one was the transition of the Royal Navy from coal to oil, which according to many historians significantly contributed to the British success on the sea and to defeating the Kaiserliche Marine. A more recent example is smartphone, a device engineered for listening to the music, watching photos and videos, and playing games on the move. The smartphone is a creative amalgamation of previously existing ideas, technologies, and brilliant marketing such as Sony's walkman, digital standards MP3(4) and QuickTime. 
We consider innovativeness and innovations a major driving force for both the economy and society that helps introduce the society into the era of liquid modernity understood as the world of reason, chances, opportunities and development (Bauman, 2000). Because of a quite common mistake that mixes up innovativeness with inventiveness, it is often said that innovations cannot be planned, that all attempts to set up durable pro-innovation organisational structures in enterprises cannot bring tangible and steady outcomes because the innovations are the results of accidents or fortunate circumstances and, therefore, cannot be efficiently managed. We are of a different opinion, namely, innovation processes can be subject to management, hence the subject to planning, implementation and further applications. For high-tech organisations and companies to maintain a comparative/ competitive advantage the issue of innovation development has become of paramount strategic importance, especially where at stake is the survivability on a highly competitive marketplace.

\section{Boosting Innovations in High-Tech Enterprises}

A classic albeit a slightly cliché-type characteristic of high-tech enterprises is that, inter alia: (i) they use cutting-edge technologies; (ii) they feature high innovativeness and creativity of staff; (iii) they develop and apply high performance work models; (iv) the lifetime of the applied solutions and technologies by these companies is short; (v) they are exposed to highly competitive market; (vi) they suffer from heterogeneous and floating customer segments; and (vii) their staffers enjoy high salaries (Jacobfeuerborn, 2005). This is really a challenging milieu, where external and internal challenges are key development factors that determine and drive daily operations and employees' behaviour. Undoubtedly, business culture, rules of operation and relationships with the market as practiced by the high-tech companies are dramatically different from those of conventional enterprises. For high-tech companies the major challenge consists in handling business initiatives in such a way that they must balance relevance and speed to the market with the need for flexibility and robustness of the underlying technologies, while taking into account that business process may extend beyond organisational boundaries to address an entire value chain/network. The high-tech enterprises have to set up new standards in terms of business processes integration, management, human resources development, work performance and pro-customer orientation. Towards this end, they tremendously need information, knowledge, customers - and employees-cantered managerial solutions and social awareness about the implications of new technologies and services proliferation. All this requires broadly understood innovation, and innovativeness management.

Innovativeness management is not an easy task. Peter F. Drucker argues that the development through innovations requires what he calls a "creative destruction", and introducing a certain level of disequilibrium into the existing order (Drucker, 1985). We are of the opinion that a pro-innovation environment requires a balanced and regular organisational structure, especially in its decision, manufacturing and/or service rendering centres, but it also includes some disordered sub-systems (sometimes located at the "peripheries" of the company) that may prima facie even look slightly chaotic. These sub-systems of disequilibrium are actually the sites where innovations are born. They are the fulcrums of 
innovation emergence and crystallisation. In these places of bifurcation semi-chaos boosts innovativeness. Now, we can say that innovativeness planning and management have to identify such sub-systems or to establish frames for them to emerge (towards this end, a few helpful methods are given in (Kelley, 2001; Napier et al., 1998)), and then to evaluate and make use of what these sub-systems produce, and if appropriate, to integrate the results with the rest of the organisation.

Innovativeness is the process that combines technological, organisational and psychological factors, which is getting more and more democratised, mainly owing to information technology and mobile communications technology. It should be noted that the democratisation of innovativeness is a new and promising phenomenon in the history of innovativeness whose consequences are hardly predictable. Information technologies allow more employees, users and customers to be involved in pro-innovation activities (Hippel, 2005), what gives rise to the emergence of innovation networks (Hippel, 2002). In what follows we shall elaborate on this matter a little bit more.

The key-word creativity economy, which assumes innovativeness and engagement of employees and customers in a lively dialog, becomes the most relevant characteristic of the present advanced micro-economy. The relationship between manufacturers and service providers and customers become the key to understand, devise and perform business. In this approach the way a company understands and handles its clients shapes the way it is managed. In the world of today, when traditional sources and means of growth are not sufficient to boost growth, only the companies having the leaders and managers who constantly think of customers and innovation, and new types of employees equipped with cutting edge competences can successfully face the incoming challenges. It seems that what is needed now, while preserving the advantages of the Six Sigma paradigm focused mainly on productivity and quality, is a leap from it towards an innovation culture and creative thinking driven by customers' actual and prospective needs.

This leap requires a re-engineering of the information infrastructure of an enterprise towards the integration of main information systems related to business processes management and human resources management that exist in the enterprise with a customer relationship management system. Schematically, this idea is depicted in the Figure 1, where the customer relationship management system encompasses and somehow determines and "inspires and nourishes" other major information systems of the company. As a digression let us note that the concept and often the practice of the staff competence building in high-tech organisations and enterprises still leaves a lot to desire. This may sound really surprising given the number of business schools populating all corners of the world. Part of the answer might be that the business schools generally follow the American model with a traditional emphasis on finance and strategy rather than the "softer" side of management that these days become more and more important and productive. The paper (Jacobfeuerborn, 2005) provides detailed characteristics of and requirements addressed to human resources development systems, human capacities building systems, including e-learning, knowledge management systems, and customer relationship management systems in the context of high-tech organisations and enterprises.

In our approach the term "integration" features several dimensions. First of all, it assumes a presence of a well-defined, consistent bottom line of the company and an overall corporate development policy which are the basis for efficient implementation of business processes, 
whether they are decision making, resource management and planning, costs control, coordination, or any other activities within the company. Moreover, "integrated" means that the system has to address needs of different categories of users within the company as well as outside the enterprise, including some participants of the distribution chain, mainly company customers, and protagonists of the supply chain. The third point is that the system has to be integrated with other computerised systems of the company so that a unified platform for providing interoperability and a seamless flow and exchange of data is in place. Next, it is of paramount importance that the interface, access mechanism and navigation philosophy are unified for all the components of the integrated system. Last but not least, the integration includes mobile access to corporate information resources and applications. Employees and managers, and in some cases also customers, have to be given a possibility to interact with the enterprise while on the move. This feature tremendously enhances flexibility of business processes, what is particularly important for fostering innovativeness. Mobility frees creativeness from place and time, which perfectly addresses the motto "innovation needs to be free".

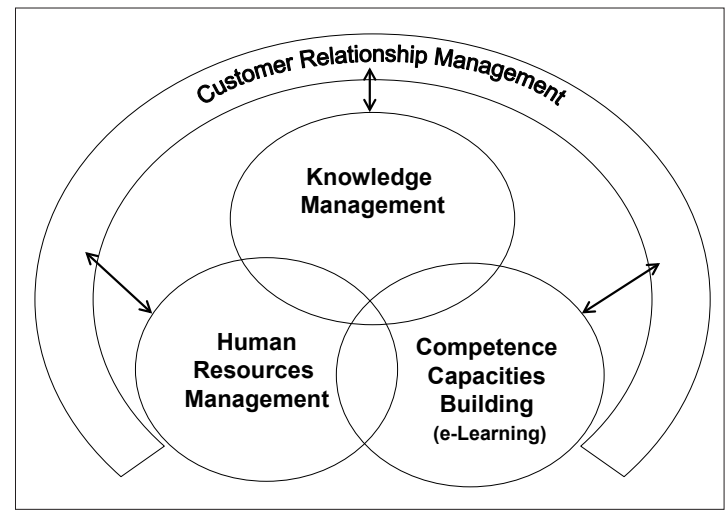

Fig. 1: Integration of information resources and processes

We argue that a portal methodology, including remote and mobile access and mechanisms, is the most appropriate to meet the above integration requirements. The justification is as follows. An enterprise portal is a point of entry that connects employees directly to structured business content and processes through a consistent interface. Company portals are multi-functional and make a multiplicity of various information and services available at a single location. A corporate portal gives its users the impression that all the company information resources and services are available in one place by means of a unified interface that can be personalised to users' aesthetic and behavioural preferences. With a single log on, portal technology provides the capability to aggregate content from multiple sources, integrates company services and business processes, integrate workflow from multiple sources, offers access to analytical information and, if necessary, facilitates commercial transactions. Portals are the right tools for creating specific collaborative communities for company's own human resources, salespeople, and customers. Noteworthy, many organisations are already using or researching a portal solution owing to the quick return on investment that comes from a quantum improvement in usability and information organisation. 


\section{Summary}

Let us recapitulate, in a nutshell, our line of reasoning adopted in this essay. We have argued that the developed world should not leave or compromise the track of modernisation that in spite of its drawbacks has thus far proven efficient and successful to address our needs and expectations regarding the standard of living and prospect. The dilemma between liberalism and welfarism is false and misleading for the world needs both the economic and social development. Presently, the driving forces of this development are information, knowledge and above all innovations. The places where innovations like to be born are mostly high-tech organisations and enterprises. To help high-tech entities give birth to innovations one has to establish favourable conditions. We have considered three aspects related to this goal, which are as follows. Firstly, one has to allow and even encourage high-tech companies for having and/or establishing in their organisational structures some points of bifurcation where free creative thoughts of the employees and experimentations could happen. Secondly, it is necessary to integrate under the umbrella of a corporate portal equipped with a unified user-friendly interface the main information system helping to handle such business processes as human resources development, human capacities building, knowledge management, and customer relationships management. These are the first processes to be integrated in order to boost innovativeness in the high-tech companies. Obviously, the integration should not be stopped at this stage and has to be continued to encompass other corporate information systems. Thirdly, access to corporate information resources and applications has to be made mobile for creativity and innovativeness have to be freed from place and time.

\section{References}

Bauman, Z. (2000). Liquid Modernity. Cambridge: Polity Press.

Blair, T. (2005). Prime Minister Tony Blair's address to the EU Parliament. The Guadrian [online] [12.12.207], https://www.theguardian.com/politics/2005/jun/23/speeches.eu

Drucker, P. F. (1985). Innovation and Entrepreneurship. New York: Harper and Row.

Dyer, J., Gregersen, H., Christensen, C., M. (2011). The Innovator's DNA: Mastering the Five Skills of Disruptive Innovators. Boston, Mass.: Harvard Business Review Press.

EC (2000). The Lisbon European Council - An agenda of economic and social renewal for Europe [online]. Rapid. European Commission Press Release Database [12.12.2017], http://europa.eu/ rapid/press-release_IP-00-191_en.htm

Hippel, E., von (2002). Horizontal Innovation Networks - By and For Users [online]. MIT Sloan School of Management Working Paper No. 4366-02. CiteSeer [12.12.2017], http://citeseerx.ist.psu.edu/viewdoc/download;jsessionid=FF1FFB9752ED41A560A91C0B4CBB383A?doi=10.1.1.12.8692\&rep=rep1\&type $=$ pdf

Hippel, E., von (2005). Democratizing Innovation [online]. The MIT Press. Massachusetts Institute of Technology [12.12.2017], http://web.mit.edu/evhippel/www/sources.htm

Horkheimer, M., Adorno, Th.W. (2002). Dialectic of Enlightenment: Philosophical Fragments (Cultural Memory in the Present). Redwood City, Ca.: Stanford University Press.

Jacobfeuerborn, B. (2005). Information Systems for Boosting Competence and Management in High-Tech Organizations. Warszawa: MOST Press.

Kelley, T. (2001). The Art of Innovation. New York, NY: Doubleday. 
Napier, R., Sidle, C., Sanaghan, P. (1998). High Impact Tools and Activities for Strategic Planning. New York, NY: McGrow-Hill.

Schumpeter, J. A. (1934). The Theory of Economic Development. Cambridge, Mass.: Harvard University Press.

\title{
Innowacyjność i procesy informacyjne w przedsiębiorstwach wysokich technologii
}

\begin{abstract}
Abstrakt
Cel/Teza: Celem pracy jest prześledzenie związków występujących pomiędzy ogólnymi procesami modernizacyjnymi, innowacyjnością i procesami informacyjnymi w organizacjach wysokich technologii oraz sformułowanie rekomendacji dotyczących wspierania innowacyjności, biorąc pod uwagę jej informacyjny wymiar. Obecnie istotną siłą sprawczą rozwoju świata jest wiedza i innowacje. Artykuł wyraźnie odróżnia innowacyjność od wynalazczości - ta pierwsza bowiem może być przedmiotem planowania i zarządzania i, jako taka, ma miejsce przede wszystkim w organizacjach i przedsiębiorstwach wysokich technologii.

Koncepcja/Metody badań: Metoda pozwalająca organizacjom wysokich technologii tworzyć warunki korzystne dla innowacyjności i opracowywać innowacyjne rozwiązania polega m.in. na: (i) zachęcaniu takich organizacji do tworzenia w ramach swych struktur organizacyjnych i procesów biznesowych punktów bifurkacji, w których może ujawniać się kreatywność i są warunki do eksperymentowania z pomysłami, (ii) integrowaniu głównych korporacyjnych systemów informacyjnych, np. systemów dotyczących produktów, know-how, zasobów ludzkich, zarządzania wiedzą, zarządzania relacjami z klientami, czy mechanizmów crowdsourcingu; szczególnie dogodnym miejscem dla takiej integracji jest portal korporacyjny (iii) wykorzystaniu potencjału modelu otwartych innowacji, (iv) zapewnieniu mobilnego dostępu do korporacyjnych zasobów informacyjnych.

Wyniki i wnioski: Przedstawiono zarys metody wspierania procesów innowacyjnych w organizacjach i przedsiębiorstwach wysokich technologii. Metoda ta może pomóc decydentom i menedżerom w projektowaniu i realizacji projektów innowacyjnych.

Oryginalność/Wartość poznawcza: Opracowana metoda jednoznacznie pokazuje, że innowacyjność w organizacjach wysokich technologii wymaga systematycznego podejścia opartego na planowaniu i regułach zarzadzania oraz na stworzeniu solidnego wsparcia informacyjnego. Wsparcie to można zapewnić przez całościową integrację zasobów i procesów informacyjnych w ramach portalu korporacyjnego.
\end{abstract}

\section{Słowa kluczowe}

Innowacja. Integracja procesów informacyjnych. Modernizacja. Społeczeństwo wiedzy. Technologie mobilne. Wysokie technologie.

Professor MIECZYSEAW MURASZKIEWICZ is a full professor at the Institute of Computer Science at Warsaw University of Technology. His research interests cover intelligent information systems, methods of knowledge representation, information services for research and development sector, and the relationships between technology and culture as well as issues of innovativeness. His recent publications are: M. Muraszkiewicz (2014). An Essay on Information Overload. Zagadnienia Informacji Naukowej, 52(1), 7-18; B. Jacobfeuerborn, M. Muraszkiewicz (2014). Some Challenges and Trends in Information Science. In: R. Bembenik et. al. (eds) Intelligent Tools for Building a Scientific Information Platform: From Research to Implementation (3-14). Springer [Studies in Computational Intelligence No. 541]; B. Jacobfeuerborn, M. Muraszkiewicz (2013). Media, Information Overload, and Information Science. In: R. Bembenik et. al. 
(eds) Intelligent Tools for Building Scientific Information Platform. Advanced Architectures and Solutions (3-13). Springer [Studies in Computational Intelligence No. 467].

Contact to the Author:

m.muraszkiewicz@ii.pw.edu.pl

Uniwersytet w Biatymstoku

Wydziat Ekonomiczno-Informatyczny w Wilnie

Kalvariju g. 135

Lt-08221 Vilnius, Lithuania

and

Instytut Informatyki

Wydziat Elektroniki i Technik Informacyjnych

Politechnika Warszawska

Nowowiejska 15/19

00-665 Warszawa 